\title{
PENGARUH PENGGUNAAN MEDIA AUDIO VISUAL TERHADAP HASIL BELAJAR MATEMATIKA SISWA SMP DI ERA PANDEMI COVID-19
}

\author{
Andi Jusmiana ${ }^{1}$, Herianto ${ }^{2}$ \\ Universitas Pejuang Republik Indonesia ${ }^{1}$, STKIP YAPTI Jeneponto ${ }^{2}$ \\ andijusmiana@gmail.com ${ }^{1}$, antoherianto47@gmail.com ${ }^{2}$
}

\begin{abstract}
Abstrak
Penelitian ini merupakan penelitian eksperimen semu (quasi eksperiment) yang bertujuan untuk mengetahui pengaruh penggunaan media audio visual (Video) terhadap hasil belajar matematika siswa. Penelitian dilaksanakan di SMP Negeri 1 Libureng Kabupaten Bone dengan populasi sebanyak 282 siswa. Melalui teknik purposive sampling, didapatkan sampel penelitian sebanyak 53 siswa, terdiri dari 25 siswa kelas IX.A sebagai Kelas kontrol dan 28 siswa kelas IX.B sebagai kelas eksperimen. Penelitian ini berlangsung selama pandemi COVID-19 sehingga segala aktivitas pembelajaran dilakukan dengan sistem Daring menggunakan google classroom. Kelas kontrol diberikan perlakuan sebagaimana yang biasa dilakukan oleh guru mata pelajaran matematika yakni pembelajaran menggunakan media gambar. Sedangkan kelas eksperimen menggunakan media audio visual. Instrumen dalam penelitian ini yakni berupa tes hasil belajar yang terdiri dari pretest dan posttest. Hasil penilitian menunjukkan rata-rata hasil belajar matematika siswa setelah pemberian pretest pada kelas kontrol sebesar 59,60 dan pada kelas eksperimen sebesar 58,57. Sedangkan hasil posttest menunjukan rata-rata hasil belajar siswa pada kelas kontrol sebesar 65,60 dan pada kelas eksperimen sebesar 75,71. Berdasarkan uji normalitas, hasil pretest dan posttest siswa pada kelas kotrol maupun kelas eksperimen berdistribusi normal dan homogen. Uji-t menunjukkan nilai sig. (2-tailed) sebesar 0,024<0,05 sehingga $\mathrm{H}_{0}$ ditolak dan $\mathrm{H}_{1}$ diterima yang berarti terdapat perbedaan nilai rerata posttest antara kelas control dan kelas eksperimen. Didapatkan pula nilai thitung sebesar 2,329 dan $t_{\text {tabel }}(0,05 / 2 ; d f)$ sebesar 2,007. Karena $t_{\text {hitung }}=2,329>t_{\text {tabel }}=2,007$ maka Ho ditolak dan h1 diterima yang berarti bahwa terdapat pengaruh penggunaan media audio visual(video) terhadap hasil belajar siswa.
\end{abstract}

Kata Kunci: Media, Audio Visual, Hasil Belajar, Pandemi, COVID-19

\section{A. Pendahuluan}

Tahun 2020 menjadi tahun bersejarah bagi peradaban umat manusia, khususnya dalam bidang Pendidikan. Organisasi Kesehatan Dunia atau World Health Organization (WHO) menetapkan wabah virus corona (COVID-19) sebagai Pandemi (Sornsa-ard, 2020). Hal tersebut berakibat pada pembatasan jarak fisik masyarakat atau physical distancing. Di Indonesia sendiri, Menteri Pendidikan dan 
Kebudayaan mewajibkan penyelenggaraan pembelajaran di seluruh satuan pendidikan dilaksanakan Daring Jaringan (Daring) sebagai upaya menanggulangi wabah tersebut (Djumiko, 2020).

Keputusan tersebut tentunya membawa dampak besar terhadap proses pembelajaran, khususnya dalam penyediaan media pembelajaran yang efektif digunakan dalam pembelajaran Daring. Berdasarkan perkembangan teknologi, media pembelajaran dapat dikelompokkan menjadi 4 (empat) kelompok, yaitu: media hasil teknologi cetak, media hasil teknologi audio visual, media hasil teknologi berdasarkan komputer, dan media hasil gabungan teknologi cetak dan komputer (Wahyu Setyaningrum, 2017).

Menurut AECT (Association of Education and Communication Technology), media adalah segala bentuk dan saluran yang digunakan untuk menyalurkan pesan atau informasi (Putranti, 2016). Apabila dikaitkan dengan kegiatan pembelajaran maka media dapat diartikan sebagai alat komunikasi yang digunakan dalam proses pembelajaran untuk membawa informasi dari pengajar ke peserta didik (Alwi, 2017).

Media berarti pengantar pesan dari pengirim kepada penerima pesan. Secara lebih khusus, pengertian media dalam proses belajar mengajar cenderung diartikan sebagai alat-alat grafis, photografis, atau elektronis untuk menangkap, memproses, dan menyusun kembali informasi visual atau verbal (Zulkifli Rusby, 2017).

Media pembelajaran ialah sarana pembelajaran yang digunakan sebagai perantara dalam proses pembelajaran. Sehingga mempertinggi efektivitas dan efisiensi dalam mencapai tujuan pembelajaran (Susanto, \& Akmal, 2019). Media Pembelajaran Sejarah Era Teknologi Informasi (Konsep Dasar, Prinsi Aplikatif, dan Perancangannya). Media pembelajaran adalah alat yang dapat membantu prose belajar mengajardan berfungsi untuk memperjelas makna pesan yang disampaikan, sehingga dapat mencapai tujuan pembelajaran dengan lebih baik dan sempurna (Cecep Kustandi dan Bambang Sutjipto, 2011).

Berdasarkan observasi di sejumlah sekolah di Kecamatan Libureng Kabupaten Bone, ada beberapa permasalahan yang ditemukan peneliti. Diantaranya pembelajarannya masih dominan mendengarkan penjelasan guru di kelas, mencatat 
atau meringkas pelajaran dan hanya menggunakan buku guru dan buku siswa saja. Media pembelajaran yang digunakan kurang bervariasi, guru hanya menggunakan Powerpoint sederhana dan banyak melakukan ceramah. Peneliti belum menemui guru yang menggunakan media video dalam pembelajaran. Hal ini membuat siswa merasa bosan, menunjukkan sikap kurang semangat belajar dan kurang tertarik dengan materi pembelajaran, bahkan ada yang asyik bermain sendiri.

Pentingnya penggunaan media video, karena dengan penggunaan media video akan mampu mencapai efektivitas proses pembelajaran, mengarahkan perhatian siswa untuk berkonsentrasi pada materi yang dipelajari sehingga poses pembelajaran menjadi menarik. Sebab, tingkat daya serap dan daya ingat (retensi) siswa terhadap materi pelajaran dapat meningkat secara signifikan jika proses pemerolehan informasi awalnya lebih besar melalui indera pendengaran dan penglihatan (Wirawan, 2020).

Materi yang ditampilkan secara visual dalam video sangat efektif dalam membantu guru menyampaikan materi yang sifatnya dinamis seperti gerakan motorik tertentu, ekspresi wajah, maupun suasana lingkungan tertentu. Materimateri tersebut memerlukan visualisasi yang mendemontrasikan hal-hal tertentu sehingga akan lebih efektif apabila disajikan melalui pemanfaatan teknologi video (Adliani, \& Wahab, 2019).

Dalam hal ini, video dapat menggambarkan suatu objek yang bergerak bersama-sama dengan suara alamiah atau suara yang sesuai, melukiskan gambar hidup dan suara, menyajikan informasi, memaparkan proses dan menjelaskan konsep-konsep yang rumit. Selain itu, tampilan video juga mengajarkan keterampilan, menyingkat atau memperpanjang waktu, dan mempengaruhi sikap sehingga siswa akan merasa sedang berada dalam kondisi yang ditampilkan dalam video (Damitri, 2020).

Video sebagai media audio-visual yang menampilkan gerak, semakin lama semakin populer dalam masyarakat kita. Pesan yang disajikan bisa berupa fakta maupun fiktif, edukatif maupun instruksional serta pesan yang bersifat informatif,. Selain itu, secara psikologis media video memiliki banyak kelebihan, diantaranya dapat menarik perhatian untuk periode-periode yang singkat dari rangsangan luar lainnya. Melalui alat perekam pita video pula, sejumlah besar penonton dapat 
memperoleh informasi dari ahli-ahli atau spesialis (Nashiruddin \& Agus Yudha Prawira Adistana, 2018).

\section{B. Metode Penelitian}

Penelitian dilaksanakan di SMP Negeri 1 Libureng Kabupaten Bone dengan populasi sebanyak 282 siswa. Melalui teknik purposive sampling, didapatkan sampel penelitian sebanyak 53 siswa, terdiri dari 25 siswa kelas IX.A sebagai Kelas kontrol dan 28 siswa kelas IX.B sebagai kelas eksperimen. Penelitian ini menggunakan Pre-test dan Post-test control Design. Dalam rancangan ini ada dua kelas sampel yaitu kelas ekseperimen dan kelas kontrol. Kelas eksperimen diberi perlakuan dengan menggunakan media pembelajaran Audio Visual (Video), sedangkan kelas kontrol menggunakan cara biasa yang dilakukan pengajar sebelumnya. Sebagai bagan ini dilukiskan pada tabel berikut:

\begin{tabular}{l}
\hline \multicolumn{4}{|c|}{ Bagan Design Pre-test dan Post-test } \\
\begin{tabular}{|l|c|c|c|}
\hline \multicolumn{1}{|c|}{ Subjek } & Pre-test & Perlakuan & Post-test \\
\hline Eksperimen & $\mathrm{O}_{1}$ & $\mathrm{X}$ & $\mathrm{O}_{2}$ \\
\hline Kontrol & $\mathrm{O}_{3}$ & & $\mathrm{O}_{4}$ \\
Keterangan: \\
$\mathrm{X}=$ perl akuan yaitu pembel ajaran dengan menggunakan media audio \\
$\quad$ visual (Video) \\
$\mathrm{O}_{1}=$ Pre-test pada kelas eksperimen \\
$\mathrm{O}_{3}=$ Pre-test pada kelas kontrol \\
$\mathrm{O}_{2}=$ post-test pada kelas eksperimen dengan perlakuan \\
$\mathrm{O}_{4}=$ Post-test pada kelas control tanpa perlakuan, Sugiyono (2013:112) \\
\hline
\end{tabular}
\end{tabular}

Peneliti menggunakan instrumen tes untuk mendapatkan data yang dibutuhkan. Soal tes yang digunakan berbentuk essay. Soal tes yang diberikan berupa pre-test dan post-test. Pre-test diberikan sebelum pembelajaran atau sebelum diberi tindakan sebanyak 5 (lima) butir soal dan post-test diberikan setelah pembelajaran atau setelah diberi tindakan sebanyak 5 (lima) butir soal.

Untuk keperluan pengujian hipotesis, maka terlebih dahulu dilakukan uji statistik dengan menggunakan program SPSS. Dari hasil pengolahan data tersebut, selanjutnya dilakukan penarikan kesimpulan dengan pengujian hipotesis yakni ujit dua pihak, dengan taraf signifikan $\alpha=0,05$ dengan ketentuan:

$\mathrm{H}_{1}: \mu 1>\mu_{2}$ (Terdapat pengaruh penggunaan media audio visual (video) terhadap hasil belajar matematika siswa). 
$\mathrm{H}_{0}: \quad \mu 1 \leq \mu_{2}$ (tidak Terdapat pengaruh penggunaan media audio visual (video) terhadap hasil belajar matematika siswa).

\section{Hasil dan Pembahasan}

Penelitian ini dilaksanakan di SMP Negeri 1 Libureng pada semester ganjil tahun ajaran 2020 - 2021, dengan populasi penelitian adalah semua sekolah menengah pertama (SMP) yang berada di Kecamatan Libureng. Sebelum instrumen tes diberikan kepada subjek penelitian, terlebih dahulu diujicobakan kepada siswa SMP Negeri 4 Libureng. Setelah melakukan validasi maka diperoleh soal pretest dan posttest masing-masing 10 butir soal pilihan ganda yang dapat digunakan.

Hasil statistik yang berkaitan dengan skor pretest dan posttest siswa pada kelompok kontrol dan kelompok eksperimen disajikan dalam tabel berikut:

Tabel 1. Statistik Hasil Pretest dan Posttest Siswa

\begin{tabular}{ccccc}
\hline \multirow{2}{*}{ Statistik } & \multicolumn{2}{c}{ Kelompok Eksperimen } & \multicolumn{2}{c}{ Kelompok Kontrol } \\
\cline { 2 - 5 } & Pretest & Posttest & Pretest & Posttest \\
\hline Ukuran Sampel & 28 & 28 & 25 & 25 \\
Skor Ideal & 100 & 100 & 100 & 100 \\
Skor tertinggi & 90 & 100 & 90 & 100 \\
Skor terendah & 30 & 40 & 20 & 40 \\
Rentang Skor & 60 & 60 & 70 & 60 \\
Skor rata-rata & 58,57 & 75,71 & 59,60 & 65,60 \\
Median & 60 & 75 & 60 & 60 \\
Standar deviasi & 18,80 & 16,20 & 18,14 & 15,31 \\
Variansi & 353,44 & 262,43 & 329,00 & 234,00 \\
\hline
\end{tabular}

Jika hasil pretest dan posttest siswa pada kelompok kontrol dan kelompok eksperimen dikelompokkan ke dalam lima kategori, maka diperoleh distribusi skor dan persentase seperti ditunjukkan pada tabel 2:

Tabel 2. Distribusi Frekuensi dan Persentase Hasil Pretest dan Posttest

\begin{tabular}{|c|c|c|c|c|c|c|c|c|c|}
\hline \multirow{3}{*}{$\begin{array}{c}\text { Interval } \\
\text { Skor }\end{array}$} & \multirow[t]{3}{*}{ Kategori } & \multicolumn{4}{|c|}{ Kelas Eksperimen } & \multicolumn{4}{|c|}{ Kelas Kontrol } \\
\hline & & \multicolumn{2}{|c|}{ Pretest } & \multicolumn{2}{|c|}{ Posttest } & \multicolumn{2}{|c|}{ Pretest } & \multicolumn{2}{|c|}{ Posttest } \\
\hline & & $\mathrm{F}$ & $\%$ & $\mathrm{~F}$ & $\%$ & $\mathrm{~F}$ & $\%$ & $\mathrm{~F}$ & $\%$ \\
\hline $0-59$ & Sangat Rendah & 12 & $42,85 \%$ & 2 & $7,14 \%$ & 10 & $40 \%$ & 5 & $20 \%$ \\
\hline $60-69$ & Rendah & 6 & $21,43 \%$ & 6 & $21,43 \%$ & 6 & $24 \%$ & 8 & $32 \%$ \\
\hline $70-79$ & Sedang & 4 & $14,29 \%$ & 6 & $21,43 \%$ & 3 & $12 \%$ & 5 & $20 \%$ \\
\hline $80-89$ & Tinggi & 3 & $10,71 \%$ & 5 & $17,86 \%$ & 4 & $16 \%$ & 5 & $20 \%$ \\
\hline $90-100$ & Sangat Tinggi & 3 & $10,71 \%$ & 9 & $32,14 \%$ & 2 & $8 \%$ & 2 & $8 \%$ \\
\hline & Total & 28 & $100 \%$ & 28 & $100 \%$ & 25 & $100 \%$ & 25 & $100 \%$ \\
\hline
\end{tabular}


Data tersebut menunjukkan bahwa skor rata-rata kemampuan mengerjakan soal Pretest dari 25 orang siswa kelas IX.A SMA Negeri 1 Libureng sebagai kelas kontrol dikategorikan sangat rendah yaitu sebesar 59,57. Terdapat 10 siswa atau $40 \%$ berada pada kategori sangat rendah, 6 siswa atau 24\% berada pada kategeori rendah, 3 siswa atau $12 \%$ berada pada kategori sedang, 4 siswa atau $16 \%$ berada pada kategori tinggi dan 2 siswa atau $8 \%$ berada pada kategori sangat tinggi. Sedangkan pada kelas IX.B sebagai kelas eksperimen yang terdiri dari 28 orang siswa yang menjadi sampel penelitian, memperoleh skor rata-rata kemampuan mengerjakan soal Pretest sebesar 58,57, dimana 12 siswa atau 42,85\% berada pada kategori sangat rendah dan 6 siswa atau 21,43\% berada pada kategori rendah, 4 siswa atau 14,29\% berada pada kategori sedang, 3 siswa atau 10,71\% berada pada kategori tinggi dan 3 siswa atau 10,71\% berada pada kategori sangat tinggi.

Selain itu, pada kelas IX.A sebagai kelas kontrol terdapat 25 orang siswa yang diberikan tes akhir (posttest), dengan pencapaian skor rata-rata sebesar 65,60, dimana 5 siswa atau $20 \%$ berada pada kategori sangat rendah, sedang dan tinggi, 8 siswa atau $32 \%$ berada pada kategori rendah dan 2 siswa lainnya atau $8 \%$ berada pada kategori sangat tinggi. Sedangkan pada kelas IX.B sebagai kelas eksperimen diketahui bahwa dari 28 orang siswa yang menjadi sampel penelitian memperoleh skor rata-rata sebesar 75,71. terdapat 2 siswa atau 7,14\% berada pada kategori sangat rendah, 6 siswa atau 21,43\% berada pada kategori rendah dan sedang, 5 siswa atau $17,86 \%$ berada pada kategori tinggi dan 9 siswa atau $32,14 \%$ berada pada kategori sangat tinggi.

Adapun skor rata-rata hasil posttest siswa kelas IX.A SMP Negeri 1 Libureng adalah 65,60 yang menunjukkan bahwa hasil belajar matematika siswa tersebut berkategori rendah. Sedangkan skor rata-rata hasil posttest siswa kelas IX.B setelah diajar menggunakan media audio visual (video) adalah 75,71\%, maka dapat disimpulkan bahwa hasil posttest siswa tersebut dikategorikan sedang.

Uji statistik inferensial digunakan dalam penelitian ini untuk menguji hipotesis. Adapun hasil uji normalitas data pretest dan posttest yang dilakukan dalam peneliltian ini yakni sebagai berikut: 
Tabel 3. Data Hasil Uji Normalitas Data Pretest Dan Posttest

\begin{tabular}{llrrrrrr}
\hline & \multirow{2}{*}{ Kelas } & \multicolumn{3}{c}{ Kolmogorov-Smirnov } & \multicolumn{3}{c}{ Shapiro-Wilk } \\
\cline { 2 - 8 } & & Statistic & df & Sig. & Statistic & df & Sig. \\
\hline Hasil & Pretest Eksperiment & .113 & 28 & $.200^{*}$ & .940 & 28 & .112 \\
\cline { 2 - 8 } Belajar & Pretest Kontrol & .131 & 25 & $.200^{*}$ & .963 & 25 & .484 \\
\cline { 2 - 8 } Siswa & Posttest Eksperiment & .138 & 28 & .185 & .942 & 28 & .127 \\
\cline { 2 - 8 } & Posttest Kontrol & .163 & 25 & .086 & .946 & 25 & .207 \\
\hline
\end{tabular}

Data pada hasil uji normalitas dikatakan normal jika nilai signifikansi Asymp sig.(2-tiled) menunjukkan angka >0,05. Demikian pula sebaliknya data tidak berdistribusi normal jika Asymp sig.(2-tiled) menunjukkan angka $<0,05$. Tabel 3 diatas menunjukan bahwa hasil belajar siswa baik pretest maupun posttest pada kelas kontrol dan kelas eksperimen menunjukan nilai Asymp sig.(2tailed) $>0,05$, sehingga dapat simpulkan bahwa tidak ada deviasi dari normalitas data dan dapat dikategorikan berdistribusi normal. Oleh karena itu analisis selanjutnya menggunakan uji statistik parametrik.

Adapun hasil uji beda rata-rata nilai pretest dilakukan dengan Independent t-test, dapat dilihat pada table berikut:

Tabel 4. Hasil Uji Beda Rata-Rata Nilai Pretest (Independent Samples Test)

\begin{tabular}{|c|c|c|c|c|c|c|c|c|c|c|}
\hline & & \multicolumn{4}{|c|}{$\begin{array}{l}\text { Levene's Test } \\
\text { for Equality } \\
\text { of Variances }\end{array}$} & \multicolumn{3}{|c|}{ t-test for Equality of Means } & & \\
\hline & & \multirow[t]{2}{*}{$\mathrm{F}$} & \multirow[t]{2}{*}{ Sig. } & \multirow[t]{2}{*}{$\mathrm{t}$} & \multirow[t]{2}{*}{ Df } & \multirow[t]{2}{*}{$\begin{array}{l}\text { Sig. } \\
(2- \\
\text { tailed })\end{array}$} & \multirow[t]{2}{*}{$\begin{array}{c}\text { Mean } \\
\text { Differe } \\
\text { nce }\end{array}$} & \multirow{2}{*}{$\begin{array}{c}\text { Std. } \\
\text { Error } \\
\text { Differe } \\
\text { nce }\end{array}$} & \multicolumn{2}{|c|}{$\begin{array}{l}95 \% \text { Confidence } \\
\text { Interval of the } \\
\text { Difference }\end{array}$} \\
\hline & & & & & & & & & Lower & Upper \\
\hline \multirow[t]{2}{*}{$\begin{array}{l}\text { Hasil } \\
\text { Belajar } \\
\text { Siswa }\end{array}$} & $\begin{array}{l}\text { Equal } \\
\text { variances } \\
\text { assumed }\end{array}$ & .142 & .708 & -.202 & 51 & .841 & -1.029 & 5.088 & -11.244 & 9.186 \\
\hline & $\begin{array}{l}\text { Equal } \\
\text { variances } \\
\text { not } \\
\text { assumed }\end{array}$ & & & -.203 & 50.677 & .840 & -1.029 & 5.078 & -11.224 & 9.167 \\
\hline
\end{tabular}

Berdasarkan hasil uji beda rata-rata pretest diperoleh nilai signifikansi uji Levena atau uji homogenitas pretest sebesar 0,708>0,05 sehingga dapat disimpulkan bahwa hipotesis (Ho) diterima yang berarti bahwa nilai pretest kelas control dan kelas eksperimen mempunyai variansi yang sama, atau dapat disebut homogen. Sedangkan untuk uji-t, jika dilihat dari Equal Variances Assumed, pada kolom sig.(2-tailed) menunjukkan angka 0,841 > 0,05 maka Ho diterima yang berarti tidak terdapat perbedaan nilai rerata antara kelas control dan kelas eksperimen. 
Adapun hasil uji beda rata-rata sampel berpasangan (Pretest-Posttest) yang digunakan untuk mengetahui apakah terdapat perbedaan rata-rata dua sampel yang berpasangan ditunjukkan dalam tabel berikut:

Tabel 5. Hasil Uji Beda Rata-rata Sampel Berpasangan (Pretest-Posttest)

\begin{tabular}{|c|c|c|c|c|c|c|c|c|c|}
\hline & & \multicolumn{5}{|c|}{ Paired Differences } & \multirow{3}{*}{$\mathrm{t}$} & \multirow{3}{*}{$\mathrm{df}$} & \multirow{3}{*}{$\begin{array}{l}\text { Sig. } \\
(2- \\
\text { tailed) }\end{array}$} \\
\hline & & \multirow[t]{2}{*}{ Mean } & \multirow{2}{*}{$\begin{array}{l}\text { Std. } \\
\text { Deviat } \\
\text { ion }\end{array}$} & \multirow{2}{*}{$\begin{array}{l}\text { Std. } \\
\text { Error } \\
\text { Mean }\end{array}$} & \multicolumn{2}{|c|}{$\begin{array}{l}\text { 95\% Confidence } \\
\text { Interval of the } \\
\text { Difference }\end{array}$} & & & \\
\hline & & & & & Lower & Upper & & & \\
\hline $\begin{array}{l}\text { Pair } \\
1\end{array}$ & $\begin{array}{l}\text { Pretest } \\
\text { Eksperiment } \\
\text { - Posttest } \\
\text { Eksperiment }\end{array}$ & -14.286 & 15.258 & 2.883 & -20.202 & -8.369 & -4.954 & 27 & .000 \\
\hline $\begin{array}{l}\text { Pair } \\
2\end{array}$ & $\begin{array}{l}\text { Pretest } \\
\text { Kontrol - } \\
\text { Posttest } \\
\text { Kontrol }\end{array}$ & -5.200 & 10.456 & 2.091 & -9.516 & -.884 & -2.487 & 24 & .020 \\
\hline
\end{tabular}

Berdasarkan output pair 1 diperoleh nilai Sig.(2-tailed) sebesar 0,000 $<0,05$ maka dapat disimpulkan "ada perbedaan rata-rata hasil belajar siswa untuk Pretest kelas eksperiment dengan posttest kelas eksperiment". Demikian pula output pair 2 diperoleh nilai Sig.(2-tailed) sebesar 0,020<0,05 maka dapat disimpulkan "ada perbedaan rata-rata hasil belajar siswa untuk Pretest kelas kontrol dengan posttest kelas control".

Selanjutnya, data hasil uji beda rata-rata nilai posttest dengan menggunakan uji independent sample menunjukkan hasil sebagai berikut:

Tabel 6. Hasil Uji Beda Rata-Rata Nilai Posttest (Independent Samples Test)

\begin{tabular}{|c|c|c|c|c|c|c|c|c|c|c|}
\hline & & \multicolumn{2}{|c|}{$\begin{array}{c}\text { Levene's Test } \\
\text { for Equality of } \\
\text { Variances } \\
\end{array}$} & \multicolumn{7}{|c|}{ t-test for Equality of Means } \\
\hline & & \multirow[t]{2}{*}{$\mathrm{F}$} & \multirow[t]{2}{*}{ Sig. } & \multirow[t]{2}{*}{$\mathrm{t}$} & \multirow[t]{2}{*}{ Df } & \multirow[t]{2}{*}{$\begin{array}{l}\text { Sig. } \\
(2- \\
\text { tailed })\end{array}$} & \multirow[t]{2}{*}{$\begin{array}{l}\text { Mean } \\
\text { Differ } \\
\text { ence }\end{array}$} & \multirow{2}{*}{$\begin{array}{l}\text { Std. } \\
\text { Error } \\
\text { Differ } \\
\text { ence }\end{array}$} & \multicolumn{2}{|c|}{$\begin{array}{l}\text { 95\% Confidence } \\
\text { Interval of the } \\
\text { Difference }\end{array}$} \\
\hline & & & & & & & & & Lower & Upper \\
\hline \multirow[t]{2}{*}{$\begin{array}{l}\text { Hasil } \\
\text { Belajar } \\
\text { Siswa }\end{array}$} & $\begin{array}{l}\text { Equal } \\
\text { variances } \\
\text { assumed } \\
\end{array}$ & .321 & .573 & 2.329 & 51 & .024 & 10.114 & 4.342 & 1.396 & 18.832 \\
\hline & $\begin{array}{l}\text { Equal } \\
\text { variances } \\
\text { not } \\
\text { assumed }\end{array}$ & & & 2.337 & 50.828 & .023 & 10.114 & 4.328 & 1.425 & 18.804 \\
\hline
\end{tabular}

Berdasarkan nilai signifikansi uji Levena atau uji homogenitas posttest sebesar 0,573 > 0,05 sehingga dapat disimpulkan bahwa hipotesis(Ho) diterima yang berarti bahwa nilai posttest kelas control dan kelas eksperimen mempunyai variansi yang sama, atau dapat disebut homogen. 
Selanjutnya hasil dari uji-t menggunakan uji independent test diketahui bahwa Equal Variances Assumed, pada kolom sig.(2-tailed) menunjukkan angka $0,024<0,05$ maka Ho ditolak dan $\mathrm{H}_{1}$ diterima yang berarti terdapat perbedaan nilai rerata posttest antara kelas control dan kelas eksperimen. Selanjutnya, berdasarkan output diatas diperoleh t-hitung sebesar 2,329 dan t-tabel(0,05/2; df) sebesar 2,007. Karena $t_{\text {hitung }}=2,329>t_{\text {tabel }}=2,007$ maka Ho ditolak dan $h_{1}$ diterima yang berarti terdapat perbedaan antara kedua kelompok sampel. Sehingga dapat disimpulkan bahwa terdapat pengaruh media audio visual (video) terhadap hasil belajar matematika siswa di SMP Negeri 1 Libureng. Dengan demikian hipotesis yang menyatakan bahwa ada pengaruh media audio visual(video) terhadap hasil belajar siswa dapat diterima.

Hasil penelitian ini sejalan dengan hasil penelitian Muhammad Chusnul Al Fasyi (2015) yang melaporkan bahwa terdapat pengaruh penggunaan media video terhadap hasil belajar IPA siswa. Hal ini ditunjukkan pada perbedaan nilai rata-rata post-test hasil belajar IPA siswa pada kelas eksperimen 80,36 lebih besar dari nilai rata-rata kelas kontrol yaitu 76,18. Begitupun dengan hasil penelitian dari Rini Puspitasari, dkk (2015) yang menyatakan bahwa dengan menggunakan media audiovisual pembelajaran lebih menarik sehingga mampu meningkatkan minat dan perhatian siswa untuk belajar, siswa menjadi lebih aktif dalam proses pembelajaran. Hal tersebut memacu keterampilan kerja ilmiah serta kerjasama dalam kelompok siswa. Hanya saja manajemen waktu harus ditingkatkan agar tujuan pembelajaran dapat tercapai.

\section{Kesimpulan}

Berdasarkan hasil penelitian di atas, maka penelitian ini menyimpulkan bahwa ada pengaruh positif dan signifikan penggunaan media audio visual (video) terhadap hasil belajar matematika siswa di SMP Negeri 1 Libureng Kabupaten Bone. Dimana, skor rata-rata hasil posttest siswa pada kelas kontrol sebesar 65,60\% atau berada pada kategori rendah, sedangkan skor rata-rata hasil posttest siswa pada kelas eksperimen sebesar $75,71 \%$, atau berada pada katgori sedang 


\section{Daftar Pustaka}

Adliani, S., \& Wahab, W. S. A. (2019). Pemanfaatan Video untuk Meningkatkan Keterampilan Berbicara Siswa Sekolah Dasar. In Prosiding Seminar Nasional Pendidikan Bahasa dan Sastra Indonesia II (Vol. 2, pp. 141-145). FBS Unimed Press.

Alwi, S. (2017). Problematika guru dalam pengembangan media pembelajaran. ITQAN: Jurnal Ilmu-Ilmu Kependidikan, 8(2), 145-167.

Al Fasyi, M. C. (2015). Pengaruh penggunaan media video terhadap hasil belajar IPA siswa kelas IV SD Negeri Ngoto Bantul Yogyakarta. BASIC EDUCATION, 4(16).

Damitri, D. E. (2020). Keunggulan Media Powerpoint Berbasis Audio Visual Sebagai Media Presentasi Terhadap Hasil Belajar Siswa SMK Teknik Bangunan. Jurnal Kajian Pendidikan Teknik Bangunan, 6(2).

Djumiko, D., Fauzan, S., \& Jailani, M. (2020). Panduan Kepala Sekolah Untuk Mengelola Sekolah Pada Masa Pandemic Covid-19. Pedagogik: Jurnal Pendidikan, 15(2), 56-69.

Kustandi, C., \& Sutjipto, B. (2011). Media pembelajaran manual dan digital. Bogor: Ghalia Indonesia, 173.

Nashiruddin, A., \& Agus Yudha Prawira Adistana, G. D. E. (2018). Analisis Kelayakan Media Video Tutorial pada Mata Kuliah Menggambar Bangunan Sipil Jurusan Teknik Sipil Fakultas Teknik Universitas Negeri Surabaya. Jurnal Kajian Pendidikan Teknik Bangunan, 2(2/JKPTB/18).

Puspitasari, R., Lesmono, A. D., \& Prihandono, T. (2015). Pengaruh model pembelajaran Poe (Prediction, Observation and Explanation) disertai media audiovisual terhadap keterampilan kerja ilmiah dan hasil belajar siswa dalam pembelajaran IPA-Fisika di SMP. Jurnal Pembelajaran Fisika, 4(3), 211-218.

Putranti, N. (2016). Cara Membuat Media Pembelajaran Online Menggunakan Edmodo. Jurnal Pendidikan Informatika dan Sains, 2(2), 139-147.

Rusby, Z., Bakhri, B. S., \& Rozi, S. (2017). Pengaruh Bauran Promosi Terhadap Peningkatan Jumlah Tamu pada Wisma Graha Az-Zahra Pekanbaru. AlHikmah: Jurnal Agama dan Ilmu Pengetahuan, 14(2), 222-241.

Setyaningrum, W., \& Waryanto, N. H. (2017). Media edutainment segi empat berbasis android: apakah membuat belajar matematika lebih menarik?. Jurnal Mercumatika: Jurnal Penelitian Matematika dan Pendidikan Matematika, 2(1), 40-56.

Sornsa-ard, T., Niramitsantiphong, A., \& Liawrungrueang, W. (2020). Management of traumatic spinal fracture in the coronavirus disease 2019 situation. Asian Spine Journal, 14(3), 385-387. 
Susanto, H., \& Akmal, H. (2019). Media Pembelajaran Sejarah Era Teknologi Informasi (Konsep Dasar, Prinsi Aplikatif, dan Perancangannya).

Wirawan, A. (2020). Memaksimalkan layanan informasi berbasis media audio visual: suatu upaya meningkatkan minat belajar siswa di SMP. JURNAL SIPATOKKONG BPSDM SULSEL, 1(2), 148-153. 